\title{
IMPLIKASI PENCEGAHAN PENULARAN CORONA MELALUI KEGIATAN CUCI TANGAN PAKAI SABUN TERHADAP PENGEMBANGAN MOTORIK HALUS ANAK USIA DINI
}

\author{
Yanti Nur Hayati \\ Institut Agama Islam Negeri Jember \\ yantinurhayati@ymail.com
}

\begin{abstract}
Corona Virus Desease or Covid-19 is a new virus that has attacked 213 countries including Indonesia. The spread of this virus is very fast so that government policies are needed to prevent transmission. One recommendation is to get used to Washing Hands with Soap (CTPS) is no exception with Early Childhood. The family has a role to teach and practice Handwashing with Soap (CTPS). The purpose of this writing is expected to contribute ideas and benefits for students, teachers or PAUD lecturers, and observers of early childhood education. The method used is descriptive in the form of conceptual writing which is the result of discussions between researchers' field observations, experiences of early childhood educators, as well as theoretical studies and previous research results that focus on Handwashing with Soap (CTPS). The results of the discussion found that CTPS by using six steps can improve children's soft motor development, so that CTPS can be used as a method of developing soft motor skills in early childhood.
\end{abstract}

Keyword: corona virus, handwashing with soap, soft motor skills

\begin{abstract}
Abstrak
Virus Corona atau Virus Covid-19 adalah virus baru yang telah menyerang ke 213 negara termasuk Indonesia. Penyebarannya virus ini sangat cepat sehingga diperlukan kebijakan pemerintah untuk pencegahan penularan. Salah satu rekomendasinya adalah membiasakan diri untuk Cuci Tangan Pakai Sabun (CTPS) tak terkecuali dengan Anak Usia Dini. Keluarga memiliki peran untuk mengajarkan dan melatih Cuci Tangan Pakai Sabun (CTPS). Tujuan penulisan ini diharapkan dapat memberikan sumbangan pemikiran serta manfaat bagi mahasiswa, guru atau dosen PAUD, dan pemerhati pendidikan anak usia dini. Metode yang digunakan adalah deskriptif berupa tulisan konsepsional yang merupakan hasil diskusi antara pengamatan lapangan peneliti, pengalaman pendidik anak usia dini, serta kajian teori dan hasil penelitian terdahulu yang berfokus pada kegiatan Cuci Tangan Pakai Sabun (CTPS). Hasil diskusi ditemukan bahwa CTPS
\end{abstract}


dengan menggunakan enam langkah dapat meningkatkan perkembangan motorik halus anak, sehingga CTPS dapat dijadikan sebagai salah satu metode pengembangan motorik halus anak usia dini.

Kata Kunci: virus corona, cuci tangan pakai sabun, motorik halus

\section{Pendahuluan}

Setidaknya ada dua virus yang sangat membahyakan hingga menyebabkan kematian, virus itu dikenal denga Middle East Respiratory Syndrome (MERS) dan Severe Acute Respiratory Syndrome (SARS). ${ }^{1}$ Dua virus hebat ini kemudian mutasi genetik yang kabarnya jauh lebih hebat dari pada Mers dan Sars.Gejala awal munculnya mutasi itu pada bulan Desember 2019 di Wuhan, China. Virus ini diberi nama Corona virus Disease-2019 disingkat Covid-19 yang telah menyebkan puluhan ribu rakyat China meninggal.

Covid-19 ini juga telah menyebar ke negara-negara Barat seperti di Italia, Jerman, Spayol dan Amerika Serikat yang tidak sedikit memakan korban. Begitu juga dengan negara-negara di timur tengah hingga negaranegara di Asia Tenggara termasuk Indonesia. Berdasarkan data yang dirilis oleh WHO pada tanggal 21 April 2020 Pukul 16.30 WIB terdapat 213 negara yang terjangkit dan terdapat 2.241.359 kasus terkonfirmasi positif dengan tingkat kematian $6,8 \%$ atau sebanyak 152.551 orang. Sedangkan menurut PHEOC Kemenkes RI pada tanggal dan jam yang sama didapatkan data 6.760 pasien terkonfirmasi positif dan 590 kasus meninggal dunia atau sebanyak $8,7^{2}$ yang ditunjukkan pada grafik berikut:

${ }^{1}$ https://www.kemkes. /go.id/article/view/20012900002/Kesiapsiagaanmenghadapi-Infeksi-Novel-Coronavirus.html diakses tanggal 19 April 2020

2https://infeksiemerging.kemkes.go.id/ diunduh tanggal 21 April 2020 jam 08.02 WIB). Berikut data perkembangan kasus covid 19 per 20 April 2020 


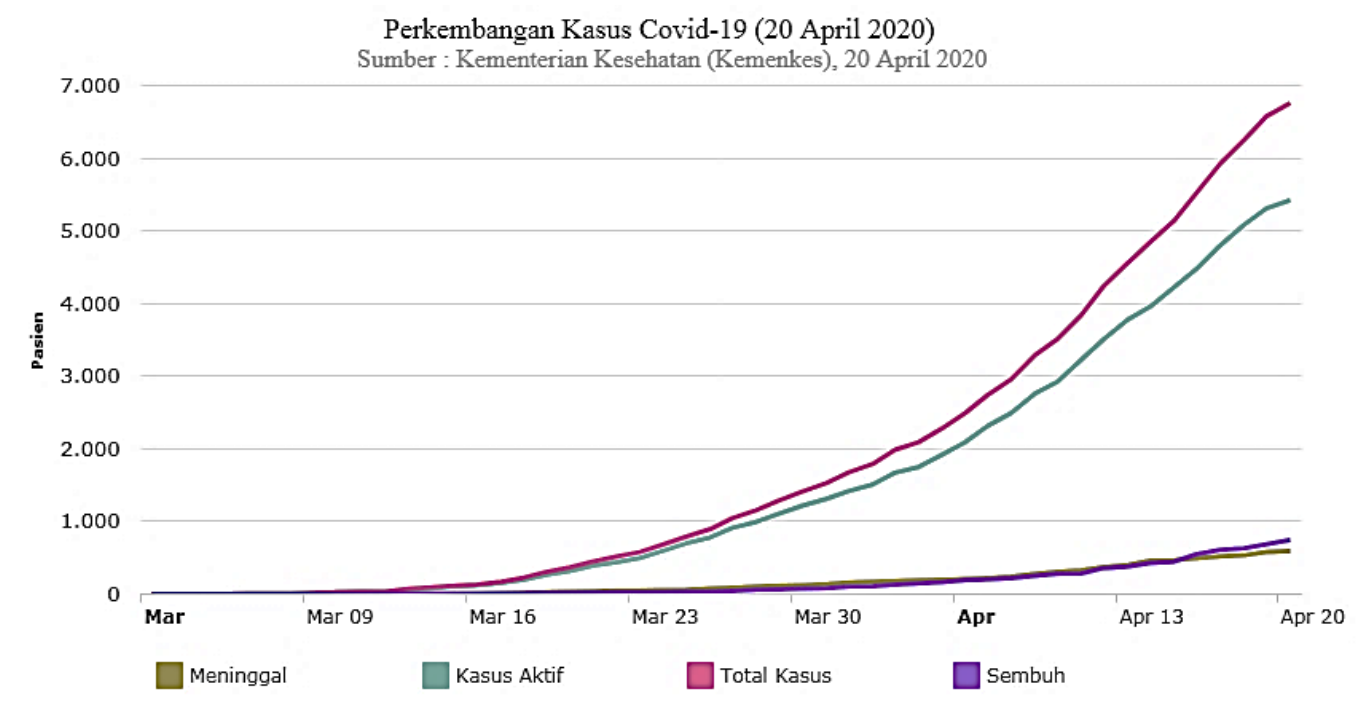

Dkatadata oosd

少databoks

\section{Grafik 1: Perkembangan Kasus Covid-19}

Grafik 1 di atas menunjukkan bahwa ada peningkatan penularan virus Covid-19 dengan sangat cepat dalam waktu yang cukup singkat. Oleh karena itu dibutuhkan keseriusan pemerintah dalam mengurangi dan mencegah terjadinya penularan virus tersebut. Pemerintah melalui Kementerian Kesehatan Republik Indonesia telah memberikan rekomendasi tentang standar dalam pencegahan penyebaran infeksi yaitu cuci tangan secara teratur menggunakan sabun dan air mengalir, menerapkan etika batuk dan bersin, menghindari kontak secara langsung dengan ternak dan hewan liar serta menghindari kontak dekat dengan siapapun yang menunjukkan gejala penyakit pernapasan seperti batuk dan bersin. Selain itu, menerapkan pencegahan dan pengendalian infeksi (PPI) saat berada di fasilitas kesehatan terutama unit gawat darurat. ${ }^{3}$

Mencuci tangan sebagai salah satu cara pencegahan terjadinya penularan virus Covid-19 dapat dijadikan sebagai salah satu metode pengembangan motorik halus anak, tentunya dengan teknik cuci tangan yang benar, yaitu cuci tangan pakai sabun (CTPS) menggunakan air menghadapi-Infeksi-Novel-Coronavirus.html diunduh tanggal 19 April 2020 jam 13.03 WIB). 
mengalir dengan menerapkan 6 (enam) langkah cuci tangan. Langkahlangkah tersebut sebagaimana yang disarankan oleh WHO, yaitu menggunakan air mengalir dan sabun (1) menggosok telapak tangan, (2) menggosok punggung tangan bagian kanan dan kiri, (3) menggosok sabun ke sela-sela jari, (4) membersihkan punggung tangan dengan gerakan saling mengunci, (5) membersihkan jempol bagian kanan dan kiri secara bergantian dengan gerakan memutar, (6) membersihkan bagian ujung jari dengan gerakan menguncup. ${ }^{4}$

Sumantri mengatakan bahwa keterampilan motorik halus adalah pengorganisasian penggunaan sekelompok otot-otot kecil seperti jari-jemari dan tangan yang sering membutuhkan kecermatan dan koordinasi mata dengan tangan. CTPS dalam pelaksanaanya menggunakan keterampilan penggunaan jari jemari, membutuhkan kecermatan dan koordinasi mata dan tangan sehingga keterampilan ini tepat digunakan sebagai salah satu metode pengembangan motorik halus anak. ${ }^{5}$ Carol Seefeldt mencontohkan motorik halus yang melibatkan otot kecil dan kordinasi mata dan tangan. Pada prakteknya setiap hari anak melakukan aktivitas dengan motorik halus misalnya mengancing baju, makan menggunakan sendok, mengikat tali sepatu dan aktivitas lainnya yang melibatkan mata dan tangan. ${ }^{6}$

Pada konteks ini maka motorik halus pada anak usia dini dapat dikontektualisasi pada kegiatan Cuci Tangan Pakai Sabun (CTPS). Selain untuk mengembangkan motorik halusnya, kegiatan ini untuk melatih anak hidup sehat ditengah pendemik. Kondisi ini sebagai strategi emperik dalam mengembangkan kepekaan anak terhadap kondisi krisis kesehatan yang sedang melanda dunia. Dengan demikian penulis berupaya untuk melakukan studi literatur tentang implikasi pencegahan penularan corona melalui kegiatan cuci tangan pakai sabun dengan pengembangan motorik halus anak usia dini.

4 https://www.kemkes.go.id/article/view/20031700003/Materi-atau-Media-FLyerCOVID-19.html.diunduh tanggal 22 April 2020 Jam 21.11 WIB).

${ }^{5}$ MS Sumantri. Pengembangan Keterampilan Motorik Anak Usia Dini.(Jakarta: Dinas Pendidikan,2005), hal.143

6 Carol seefeldt \& barbara awasik, Pendidikan Anak Usia Dini Edisi Kedua (PT Indeks: Jakarta 2008),hlm,68 


\section{Metode}

Metode dalam penulisan ini adalah deskriptif berupa tulisan konsepsional yang merupakan hasil analisis terhadap teks-teks yang relevan serta kajian teori dan hasil penelitian terdahulu yang berfokus pada kegiatan Cuci Tangan Pakai Sabun (CTPS) sebagai salah satu metode pengembangan motorik halus AUD yang dapat dimasukkan dalam kurikulum PAUD. Tujuan penulisan ini diharapkan dapat memberikan sumbangan pemikiran serta manfaat bagi mahasiswa, guru atau dosen PAUD, dan pemerhati pendidikan anak usia dini.

\section{Hasil dan Diskusi}

\section{A. Pencegahan Penyebaran Virus Covid 19}

Direktorat Jenderal Pencegahan dan Pengendalian Penyakit (P2P) Kementerian Kesehatan RI (2020) telah menyusun Buku Pedoman Pencegahan dan Pengendalian Coronavirus Disease (Covid-19) Revisi Ke-4. Dalam pedoman tersebut pencegahan dibagi menjadi :

Pertama, pencegahan level individu. Pada level ini upaya yang dilakukan oleh individu dengan upaya Kebersihan Personal dan Rumah Terdapat beberapa prinsip yang perlu diikuti untuk membantu mencegah COVID-19, yaitu menjaga kebersihan diri/personal dan rumah dengan cara:

Mencuci tangan lebih sering dengan sabun dan air setidaknya 20 detik atau menggunakan pembersih tangan berbasis alkohol (hand sanitizer), serta mandi atau mencuci muka jika memungkinkan, sesampainya di rumah atau di tempat bekerja, setelah membersihkan kotoran hidung, batuk atau bersin dan ketika makan atau mengantarkan makanan. Hindari menyentuh mata, hidung, dan mulut dengan tangan yang belum dicuci, jangan berjabat tangan, hindari interaksi fisik dekat dengan orang yang memiliki gejala sakit, Tutupi mulut saat batuk dan bersin dengan lengan atas bagian dalam atau dengan tisu lalu langsung buang tisu ke tempat sampah dan segera cuci tangan, Segera mengganti baju/mandi sesampainya di rumah setelah berpergian, bersihkan dan berikan disinfektan secara berkala pada benda-benda yang sering disentuh 
dan pada permukaan rumah dan perabot (meja, kursi, dan lain lain), gagang pintu dan lain-lain.

Peningkatan imunitas diri dan mengendalikan komorbid dalam melawan penyakit COVID-19 dan menjaga sistem imunitas diri merupakan hal yang penting, terutama untuk mengendalikan penyakit penyerta (komorbid). Terdapat beberapa hal yang dapat meningkatan imunitas diri pada orang yang terpapar Covid-19, yaitu sebagai berikut: konsumsi gizi seimbang, aktifitas fisik/senam ringan, istirahat cukup, suplemen vitamin, tidak merokok dan mengendalikan komorbid (misal diabetes mellitus, hipertensi, kanker).

Kedua, pencegahan level masyarakat, yaitu pembatasan interaksi fisik dan pembatasan sosial (Physical Contact/Physical Distancing dan Social Distancing). Pembatasan sosial adalah pembatasan kegiatan tertentu penduduk dalam suatu wilayah. Pembatasan sosial ini dilakukan oleh semua orang di wilayah yang diduga terinfeksi penyakit. Pembatasan sosial berskala besar bertujuan untuk mencegah meluasnya penyebaran penyakit di wilayah tertentu. Pembatasan sosial berskala besar paling sedikit meliputi: meliburkan sekolah dan tempat kerja; pembatasan kegiatan keagamaan; dan/atau pembatasan kegiatan di tempat atau fasilitas umum. Selain itu, pembatasan sosial juga dilakukan dengan meminta masyarakat untuk mengurangi interaksi sosialnya dengan tetap tinggal di dalam rumah maupun pembatasan penggunaan transportasi publik.

Pembatasan sosial dalam hal ini adalah jaga jarak fisik (physical distancing), yang dapat dilakukan dengan cara: Dilarang berdekatan atau kontak fisik dengan orang mengatur jarak minimal 1 meter, tidak bersalaman, tidak berpelukan dan berciuman. Hindari penggunaan transportasi publik (seperti kereta, bus, dan angkot) yang tidak perlu, sebisa mungkin hindari jam sibuk ketika berpergian. Bekerja dari rumah (Work From Home) jika memungkinkan dan kantor memberlakukan ini. Dilarang berkumpul massal di kerumunan dan fasilitas umum. Hindari bepergian ke luar kota/luar negeri termasuk ke tempat-tempat wisata. Hindari berkumpul teman dan keluarga, termasuk berkunjung/bersilaturahmi tatap muka dan menunda kegiatan bersama. Hubungi mereka 
dengan telepon, internet dan media sosial. Gunakan telepon atau layanan online untuk menghubungi dokter atau fasilitas lainnya. Jika anda sakit, Dilarang mengunjungi orang tua/lanjut usia. Jika anda tinggal satu rumah dengan mereka, maka hindari interaksi langsung dengan mereka. Untuk sementara waktu, anak sebaiknya bermain sendiri di rumah serta dapat melaksanakan ibadah di rumah.

Semua orang harus mengikuti ketentuan ini. Penulis menghimbau untuk mengikuti petunjuk ini dengan ketat dan membatasi tatap muka dengan teman dan keluarga, khususnya jika Anda: Berusia 60 tahun keatas Memilik penyakit komorbid (penyakit penyerta) seperti diabetes melitus, hipertensi, kanker, asma dan penyakit paru obstruksi kronik (PPOK) dan lain-lain.

Ibu hamil menerapkan etika batuk dan bersin menerapkan etika batuk dan bersin meliputi: Jika terpaksa harus bepergian, saat batuk dan bersin gunakan tisu lalu langsung buang tisu ke tempat sampah dan segera cuci tangan. Jika tidak ada tisu, saat batuk dan bersin tutupi dengan lengan atas bagian dalam. ${ }^{7}$

Ketiga, cuci tangan pakai sabun. Salah satu perilaku hidup bersih dan sehat (PHBS) yang selalu digaungkan sejak lama untuk menjaga kesehatan dan kebersihan pribadi adalah mencuci tangan. Perilaku ini seharusnya menjadi kebiasaan yang sangat baik, karena selain untuk menjaga kesehatan dan kebersihan, agama juga mengajarkannya.

Tangan merupakan media yang sangat ampuh untuk berpindahnya penyakit, karena tangan digunakan untuk memegang benda-benda yang seringkali tidak kita ketahui dengan pasti kebersihannya. Salah satu contoh adalah ketika kita memegang handle pintu atau pegangan dalam kendaraan, kita tidak pernah tahu apakah ada agen penyakit (virus/bakteri) yang menempel disana, bisa jadi sebelumnya dipegang oleh orang yang batuk/bersin ditutup oleh tangannya. Kemudian tangan yang sudah memegang handle pintu tersebut menutup mulut yang menguap atau langsung memegang makanan. Jelas sudah terjadi proses perpindahan

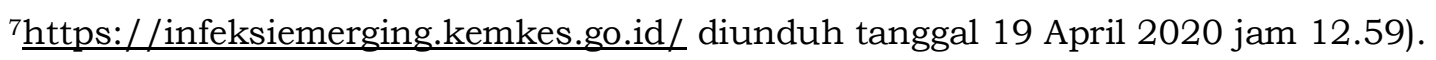


agen penyakit di sana. Jika saat itu daya tahan tubuh kita lemah, dalam masa inkubasi kita pun akan mengalami gejala yang sama.

Mencuci tangan sangat diutamakan pada waktu-waktu penting, antara lain sebelum makan, setelah buang air besar, sebelum menjamah makanan, sebelum menyusui/menyiapkan susu bayi, dan setelah beraktifitas. Sebagai kebiasaan yang baik, mencuci tangan perlu memenuhi cara yang benar, agar kita yakin bahwa seluruh permukaan tangan sudah terbasuh dan benar-benar bersih. Urutan cara-cara tersebut tergambar dalam flyer berikut ini:

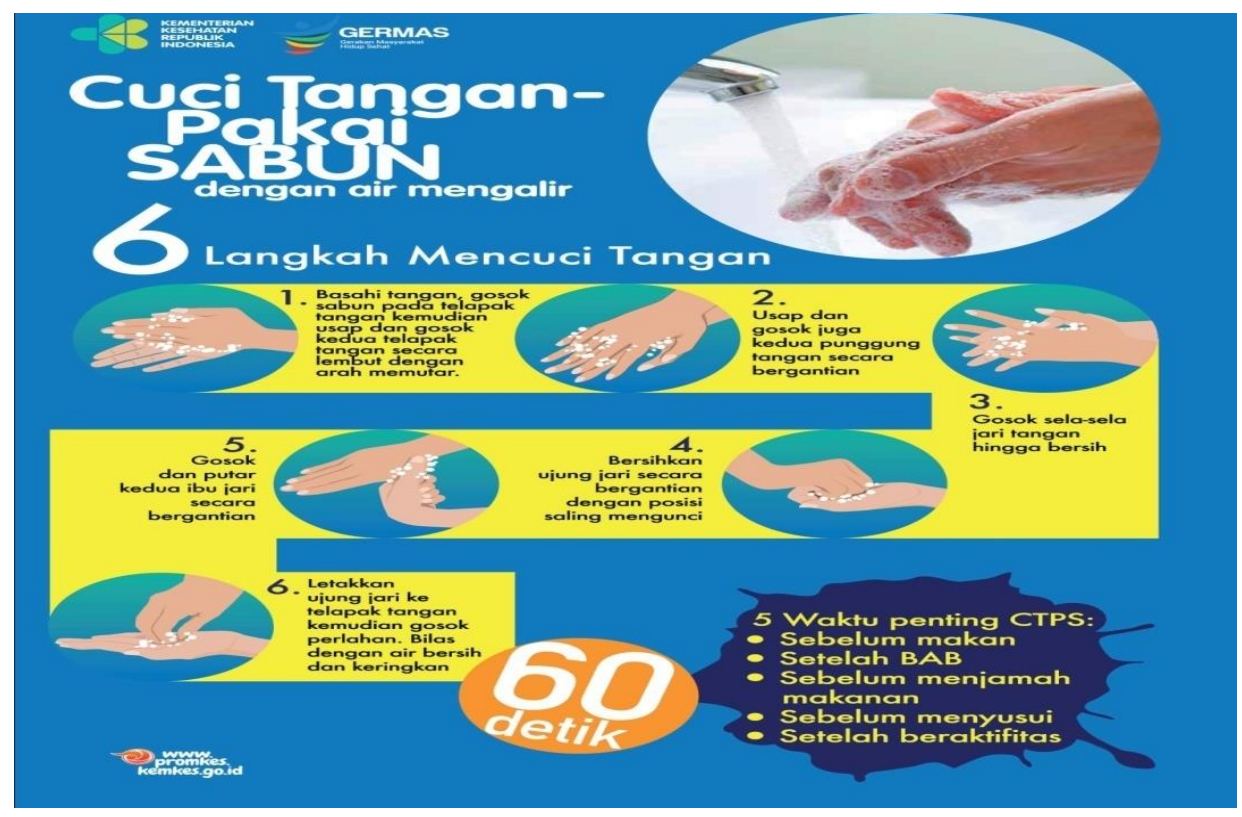

Gambar 1: Enam Langkah Mencuci Tangan ${ }^{8}$

Berdasarkan gambar 1, langkah pertama, basahi tangan, gosok sabun pada telapak tangan kemudian usap dan gosok kedua telapak tangan secara lembut dengan arah memutar; kedua, usap dan gosok jga kedua punggung tangan secara bergantian; ketiga, gosok sela-sela jari tangan hingga bersih; keempat, bersihkan ujung jari secara bergantian dengan posisi saling mengunci; kelima, gosok dan putar kedua ibu jari secara bergantian; keenam, letakkan ujung jari ke telapak tangan kemudian gosok perlahan, bilas dengan air bersih dan keringkan.

8Sumber : (https://infeksiemerging.kemkes.go.id/ diunduh tanggal 19 April 2020 jam 12.59) 
Gambar 1 merupakan urutan cara mencuci tangan menggunakan sabun dan air mengalir. Jika tidak menemukan air dan sabun, kita dapat menggantinya dengan larutan berbahan dasar alkohol yang biasa disebut hand-sanitizer. Urutannya sama dengan mencuci tangan menggunakan air dan sabun, hanya dimulai dengan menuangkan larutan hand-sanitizer secukupnya. ${ }^{9}$

\section{B. Implikasi Pencegahan Penularan Corona melalui kegiatan cuci tangan pakai sabun dengan Pengembangan Motorik Halus Anak Usia Dini}

\section{Cuci Tangan Pakai Sabun}

Mencuci tangan menggunakan sabun merupakan sensasi menyenangkan tersendiri bagi anak. Sabun yang digunakan cuci tangan dapat berupa sabun cair atau sabun batangan. Sifat sabun batangan yang licin dan kenyal melatih anak untuk memegang, mengenggam, meremas, dan mencengram agar sabun tidak jatuh dan dapat mengeluarkan busa. Kegiatan anak dalam menggunakan sabun tersebut hampir sama dengan permainan slime. Keduanya merupakan sebuah latihan untuk membantu pengembangan kontrol motorik halus anak.

Kegiatan bermain untuk meningkatkan keterampilan motorik halus bisa dilakukan dengan bermain slime. Permainan Slime adalah permainan yang cara bermain dan medianya hampir sama dengan play Dough, menurut Einon tentang permainan cerdas untuk anak usia 2-6 tahun, playdough sangat cocok untuk anakanak kecil cukup lembut untuk diremas, namun cukup elastis untuk dibuat sebuah bentuk. Kegiatan bermain slime ini mengajarkan anak bahwa mereka dapat membuat sesuatu, meningkatkan pengendalian jari tangan, dan koordinasi tangan dan mata, selain itu, kegiatan ini membuat mereka mampu mengekspersikan diri melalui kesenian. ${ }^{10} \mathrm{Hal}$ ini didukung oleh pendapat Wolfgang yang menyatakan "fluids materials have high sensorimotor quality and easily transform their shape and generally gave

${ }^{9}$ https://infeksiemerging.kemkes.go.id/ diunduh tanggal 19 April 2020 jam 12.59)

${ }^{10}$ Mita Agustina, Meningkatkan Keterampilan Motorik Halus Anak Melalui Bermain Playdough di Play Group (Surabaya :2015), hal 2. 
little or no form." ${ }^{11}$ Peryantaan tersebut artinya bahan-bahan zat cair memiliki sifat sensorimotor yang tinggi dan dapat dengan mudah berubah bentuk dan pada umumnya sedikit berbentuk atau tidak berbentuk sama sekali

Beda lagi ketika anak menggunakan sabun cair sebagai sarana cuci tangan. Anak berupaya untuk mengeluarkan sabun cair melalui telapak tangan dan jari-jarinya. Tindakan ini dapat melatih kekuatan otot dan tulang serta meningkatkan kinerja syaraf. Seidaknya telapak tangan memiliki 34 otot dan 27 tulang dan sejumlah sendi, total seluruh jumlah tulang di tangan membentuk hampir seperempat dari jumlah tulang tubuh manusia. Kemampuan gerak tangan dikendalikan seluruhnya oleh otak, bahkan sekitar seperempat bagian otak memiliki tugas untuk mengontrol perpindahan otot-otot di tangan untuk menggerakkan jari.

Menurut Rafey, efek latihan dapat merangsang faktor pertumbuhan otak (brain growth factor). Dengan demikian latihan menekan untuk mengeluarkan sabun cair merupakan salah satu teknik latihan yang berfungsi untuk mempersiapkan sel-sel saraf agar terhubung lebih mudah dan lebih kuat. Latihan dapat meningkatkan aliran darah ke otak sehingga pembuluh darah terangsang dan akses otak untuk mendapatkan energi serta oksigen meningkat. Meningkatnya aliran darah ke otak secara khusus menyebabkan stimulasi terhadap gyrus dentata, suatu area di otak yang membantu pembentukan memori. Di samping itu, peningkatan serotonin, dopamin, BDNF akan memperkuat ikatan antar sel saraf. BDNF bertanggung jawab atas pembentukan dan daya tahan yang disebabkan oleh latihan saraf terhadap kerusakan dan stres. BDNF banyak ditemukan di hipokampus, suatu area di otak yang secara langsung terlibat dalam proses belajar. ${ }^{12}$

${ }^{11}$ Charles H Wolfgangand Mary Wolfgang, School for Young Children Developmentaly Appropriate Praticies, (Needham Heigh : Alin and Bacon, 1992), hal.31.

${ }^{12}$ Eunike R. Rustiana,2011. Efek Psikologis dari Pendidikan Jasmani ditinjau dari Teori Neurosains dan Teori Kognitif Sosial Jurnal Media Imu Keolahragaan Indonesia Volume 1.(2):199 


\section{Penggunaan Air Mengalir}

Mencuci tangan yang benar adalah dengan menggunakan air yang mengalir. Dengan tujuan kotoran, kuman dan bekas sabun akan luruh terbawa air. Ada beberapa persyaratan sarana penggunaan air untuk cuci tangan, antara lain jernih, tidak berwarna dan tidak berbau. Suhu air bukan menjadi persyaratan untuk cuci tangan, dingin atau hangat memiliki efek pembersihan yang sama.

Selain memiliki efek pembersihan, air juga dapat dijadikan sebagai sarana untuk terapi atau disebut dengan hydrotheraphy. Hydrotheraphy adalah penggunaan air untuk menyembuhkan dan meringankan berbagai keluhan. Air biasa digunakan dalam banyak cara dan kemampuannya sudah diakui sejak dahulu, terutama di kerajaan Yunani, kekaisaran Romawi dan Kebudayaan Turki juga oleh masyarakat Eropa dan Tiongkok kuno. Menurut Sustrani, dkk dalam Nanjar Nur Mayesa Masyarakat umum juga menyadari bahwa manfaat air hangat adalah untuk membuat tubuh lebih rileks, menghilangkan rasa pegalpegal, kaku di otot dan mengantar agar tidur lebih nyenyak. Selain itu air hangat membuat kita merasa santai, meringankan sakit dan tegang pada otot dan memperlancar peredaran darah. ${ }^{13}$

Air dingin juga memiliki efek yang baik untuk tubuh. Tamsuri (2007) mengatakan pemberian kompres dingin dipercaya dapat meningkatkan pelepasan endorfin yang memblok transmisi stimulus nyeri dan juga menstimulasi serabut saraf berdiameter besar A-Beta sehingga menurunkan transmisi implus nyeri melalui serabut kecil Adelta dan serabut saraf C. tindakan kompres dingin selain memberikan efek menurunkan sensasi nyeri, kompres dingin juga memberikan efek fisiologis seperti menurunkan respon inflamasi jaringan, menurunkan aliran darah dan mengurangi edema. ${ }^{14}$

13 Mayesa, Nanjar Nur. 2017. Pengembangan Alat Hydrotherapy Kaki Berbasis Sensor Temperature Ds18b20 dengan Mikrokontroler Arduino Nano Atmega 328. http://repository.upi.edu/29859/4/S_IKOR_1301819_Chapter1.pdf.hal.1

14 Tamsuri, A . 2007. Konsep dan Penatalaksanaan Nyeri. Jakarta: EGC. 
Efek air mengalir yang lain adalah suara gemericiknya. Menurut Liputan 6 (2018) ternyata mendengar suara air bisa membuat seseorang lebih tenang dan nyaman. Para psikolog bahkan menggunakannya sebagai terapi agar agar tidur lebih nyenyak dan berkualitas. Orfeu Buxton, peneliti dari Live Science, menuturkan bahwa suara gemericik air bisa memengaruhi pikiran seseorang agar tetap tenang, nyaman, dan tidak khawatir dengan keadaan. Selain itu, suhu udara di sekitar juga akan terasa mendukung suasana damai tersebut.

Adapun menurut ahli biologi kelautan Wallace $\mathrm{J}$ Nichols, rasa tenang ketika dekat dengan air adalah naluri umum seorang manusia. Hal ini mendorong orang-orang untuk membangun lingkungan air di area rumah untuk mendapat ketenangan. Banyak rumah-rumah elit diperkotaan didesain dengan konsep yang memadukan antara rumah ramah lingkungan dengan air sebagai salah satu bagian interior yang tidak bisa dipisahkan.

\section{Gerakan Cuci Tangan}

Gerakan cuci tangan pakai sabun (CTPS) yang menggunakan 6 langkah merupakan gerakan motorik halus karena menggunakan kemampuan jari-jemari dan pergelangan tangan. Hal ini sesuai dengan Sujiono bahwa motorik halus adalah gerakan yang hanya melibatkan bagian-bagian tubuh tertentu saja dan dilakukan oleh otot-otot kecil, seperti keterampilan menggunakan jari-jemari tangan dan gerakan pergelangan tangan yang tepat. Gerakan ini membutuhkan koordinasi mata dan tangan yang cermat. Demikian juga yang disampaikan oleh Menurut Hurlock Perkembangan gerak motorik halus adalah meningkatnya pengkoordinasian gerak tubuh yang melibatkan otot dan saraf yang jauh lebih kecil atau detail. Kelompok otot dan saraf inilah yang nantinya mampu mengembangkan gerak motorik halus seperti meremas kertas, menyobek, menggambar, menempel, dan sebagainya. ${ }^{15}$

15 E. Hurlock, Psikologi perkembangan. Alih bahasa: dr. Med. Metasari T. \& Dra. Muslichah Z. (Jakarta: Erlangga, 1996),hal.45 
Gerakan motorik halus yang terlihat saat usia Taman KanakKanak, antara lain adalah anak mulai bisa menyikat giginya, menyisir, dan memakai sepatu sendiri. Perkembangan motorik merupakan proses memperoleh keterampilan dan pola gerakan yang dapat di lakukan anak. Misalnya dalam kemampuan motorik halus pada anak belajar ketepatan koordinasi tangan dan mata. Anak juga belajar menggerakan pergelangan tangan agar lentur dan anak belajar berkreasi, seperti menggunting kertas, menyatukan dua lembar kertas, menggambar, dan mencuci tangan tapi tidak semua anak memiliki kematangan untuk menguasai kemampuan pada tahap yang sama. Oleh karena itu dibutuhkan stimulasi yang tepat agar anak dapat berkembang secara optimal.

Kebijakan pemerintah untuk stay at home, belajar dan bekerja di rumah sebagai solusi pencegahan penularan corona merupakan moment yang penting yang dapat dimanfaatkan orang tua untuk mengajarkan dan melatih anak usia dini agar perkembangannya menjadi optimal. Salah satu kegiatan Kegiatan yang harus diajarkan oleh ibu-ibu yang memiliki anak usia dini adalah Cuci Tangan Pakai Sabun (CTPS). Selain memberikan pengajaran tentang Perilaku Hidup Bersih dan Sehat (PHBS) juga dapat dijadikan sebagai salah satu metode pengembangan motorik halus apalagi jika dilakukan secara kontinu dan rutin. Pengembangan motorik halus ini merupakan modal dasar anak untuk menulis.

Alasan lain bahwa cuci tangan pakai sabun (CTPS) dapat meningkatkan pengembangan kemampuan motorik halus anak adalah bahwa ada beberapa gerakan massage atau pijatan, seperti gerakan memutar yang dilakukan oleh telapak tangan, gerakan menekan dan meremas-remas, yang kesemuanya itu dapat meningkatkan kinerja syaraf dan otot yang membentuk gerakan motorik halus itu sendiri.

Menurut Henderson dalam andina Massage (pijatan) adalah tindakan penekanan oleh tangan pada jaringan lunak, biasanya otot tendon atau ligamen, tanpa menyebabkan pergeseran atau perubahan posisi sendi guna menurunkan nyeri, menghasilkan relaksasi, dan/atau meningkatkan sirkulasi. Gerakan-gerakan dasar meliputi : gerakan memutar yang dilakukan oleh telapak tangan, gerakan menekan dan 
mendorong kedepan dan kebelakang menggunakan tenaga, menepuknepuk, memotong-motong, meremas-remas, dan gerakan meliuk-liuk. Setiap gerakan gerakan menghasilkan tekanan, arah, kecepatan, posisi tangan dan gerakan yang berbeda-beda untuk menghasilkan efek yang di inginkan pada jaringan yang di bawahnya. ${ }^{16}$

Gerakan mengunci, menggosok-gosok telapak dan pungung tangan serta menekan ujung jari pada telapak tangan merupakan gerakan memberikan rangsangan secara refleks (spontan). Rangsangan tersebut akan mengalirkan semacam gelombang kejut atau listrik menuju otak. Gelombang tersebut diterima otak dan diproses dengan cepat, lalu diteruskan menuju saraf pada organ tubuh yang mengalami gangguan, sehingga sumbatan di jalur energi menjadi lancar. ${ }^{17}$

Di sisi lain gerakan cuci tangan dapat meningkatkan kemampuan motorik halus melalui latihan yang berpengaruh pada tulang, otot dan sendi, menimbulkan perasaan senang bagi anak yang dapat mempengaruhi kinerja persyarafan, dan pijatan yang dapat memperlancar peredaran darah. Hal ini sesuai dengan Kuhlen dan Thomson dalam Yusuf yang mengemukakan bahwa perkembangan fisik individu meliputi empat aspek, yaitu (1) sistem saraf yang sangat mempengaruhi perkembangan kecerdasan dan emosi; (2) otot-otot yang mempengaruhi perkembangan kekuatan dan kemampuan motorik; (3) kelenjar endokrin, yang menyebabkan munculnya pola-pola tingkah laku baru, seperti pada remaja berkembang perasaan senang untuk aktif dalam suatu kegiatan yang sebagian anggotanya terdiri atas lawan jenis; dan (4) struktur fisik/tubuh yang meliputi tinggi, berat dan proposi. ${ }^{18}$

16 Andinna Dwi Utami \& Imelda Rahmayunia Kartika,2018.Terapi Komplementer Guna Menurunkan Nyeri Pasien Gastritis. REAL in Nursing Journal (RNJ), Vol. 1, No. 3 Utami, A.D. \& Kartika, I.R. (2018). RNJ. 1(3) : 123-132

17 Hanggarwati, N. D. 2015. Analisis Praktik Klinik Keperawatan Pada Pasien Gastritis Dalam Dan Pijat Efflurage Terhadap Nyeri Abdomen. Karya Ilmiah. https://ojs.fdk.ac.id/index.php/Nursing/index

18 Syamsu Yusuf. Psikologi Perkembangan Anak dan Remaja. (Bandung: PT Remaja Rosdakarya,2006),hal.101 
Jadi gerakan mencuci tangan dimasa pandemik selain mendorong hidup sehat perilaku ini juga membentuk kecerdasan emosi, membentuk kemampuan motirik halus melalui gerakan-garakan tangan, pembiasaan yang menyenangkan serta dapat membantu menguatkan otot-otot pada pergelangan tangan. Gerakan mencuci tangan sebagai awal membentuk karakter disiplin pada anak, serta membentuk kepedulian terhadap kesehatan jasadiyahnya.

\section{Kesimpulan}

Salah satu cara untuk pencegahan penularan virus corona adalah dengan membiasakan Cuci Tangan Pakai Sabun (CTPS). Kegiatan ini dapat diajarkan dan dilatih oleh keluarga yang memiliki anak usia dini. Selain sebagai pembentukan Perilaku Hidup Bersih dan Sehat (PHBS), CTPS juga dapat dijadikan sebagai salah satu metode pengembangan motorik halus anak usia Dini.

Adapun indikator ketercapaian pada aktivitas Cuci Tangan Pakai Sabun (CTPS) adalah anak dapat melakukan gerakan memutar telapak tangannya, gerakan menekan dan meremas-remas serta gerakan meliukliuk. Dari Setiap gerakan gerakan tersebut dapat menghasilkan tekanan, arah, kecepatan, posisi tangan dan gerakan yang berbeda-beda untuk menghasilkan efek yang di inginkan pada jaringan.

\section{Daftar Pustaka}

Andinna Dwi Utami \& Imelda Rahmayunia Kartika,2018.Terapi Komplementer Guna Menurunkan Nyeri Pasien Gastritis. REAL in Nursing Journal (RNJ), Vol. 1, No. 3 Utami, A.D. \& Kartika, I.R. (2018). RNJ. 1(3) : 123-132

Bambang Sujiono dkk. 2008. Metode Pengembangan Fisik. Jakarta: Universitas Terbuka.

Dede Feriyanti. 2017 Keterkaitan Bermain Slime dengan Keterampilan Motorik Halus pada Anak Usia 4-5 Tahun (Studi Pustaka/Library Research)http://lib.unj.ac.id/tugasakhir/index.php?p=show_detail\&i $\mathrm{d}=45904 \&$ keywords diunduh tanggal 23 April 2020 jam 15.00. 
Hanggarwati, N. D. 2015. Analisis Praktik Klinik Keperawatan Pada Pasien Gastritis Dalam Dan Pijat Efflurage Terhadap Nyeri Abdomen. Karya Ilmiah. https://ojs.fdk.ac.id/index.php/Nursing/index

Hurlock, E. 1996. Psikologi perkembangan. Alih bahasa: dr. Med. Metasari T. \& Dra. Muslichah Z. Jakarta: Erlangga

Kemenkes. 2020. Kesiapsiagaan Menghadapi Infeksi Novel Corona Virus. (https://www.kemkes.go.id/article/view/20012900002/Kesiapsiagaa n-menghadapi-Infeksi-Novel-Coronavirus.html diunduh tanggal 19 April 2020 jam 13.03 WIB).

Kemenkes. 2020. Infeksi Emerging. https://infeksiemerging. kemkes.go.id/ diunduh tanggal 21 April 2020 jam 8.02 WIB.

Kemenkes. 2020. Kesiapsiagaan menghadapi Infeksi Novel Coronavirus. https://www.kemkes.go.id/article/view/20012900002/Kesiapsiagaa n-menghadapi-Infeksi-Novel-Coronavirus.html diunduh tanggal 19 April 2020 jam 13.03 WIB

Kemenkes. 2020. Materi atau Media Falyer Covid 19. ( https://www.kemkes.go.id/article/view/20031700003/Materi-atauMedia-FLyer-COVID-19.html.diunduh tanggal 22 April 2020 Jam 21.11 WIB).

Liputan 6. 2018. Kenapa Dengar Suara Air Bikin Tenang Begini Penjelasan Pakar https://www.liputan6.com/citizen6/read/3387116/kenapadengar-suara-air-bikin-tenang-begini-penjelasan-pakar diakses tanggal 19 april 2020 jam 14.07

Mayesa, Nanjar Nur. 2017. Pengembangan Alat Hydrotherapy Kaki Berbasis Sensor Temperature Ds18b20 dengan Mikrokontroler Arduino Nano Atmega $328 . \quad$ http://repository.upi.edu/29859/ 4/S_IKOR_1301819_Chapter1.pdf

Rachmah, L.A. 2009. Pendidikan Jasmani dan Prestasi Akademik: Tinjauan Neurosains. Jurnal Pendidikan Jasmani Indonesia. 6 (1)

Sandra, K. 2014. Manfaat Bermain Slime In Terapi Bermain. Jakarta : Alfabeta.

Setiaji, Bamandhita Rahma (2018). Jari Tidak Punya Otot. https://hellosehat.com/hidup-sehat/fakta-unik/jari-tidak-punyaotot/ diunduh 23 April 2020 Jam 18.00 WIB.

Tamsuri, A . 2007. Konsep dan Penatalaksanaan Nyeri. Jakarta: EGC.

Vasilyeva, E.N. and Shcherbakov, A.V. 2016. Parental Roles and Types of Parentings as Determinats of a Preschooler's Emotional and Personal 
Judul: Implikasi Pencegahan Penularan Corona Melalui Kegiatan Cuci Tangan Pakai Sabun Terhadap

Well being, procedia social and behavioral Sciences. The Author(s), 233(May), PP 144-149, doi: 10.1016/j.sbspro. 2016.10.172.

Yusuf, Syamsu. 2006. Psikologi Perkembangan Anak dan Remaja. Bandung: PT Remaja Rosdakarya. 